\title{
A Preliminary Investigation on the Status of the Wildlife Trade in Guangxi, China
}

\author{
LI YIMING LI DIANMO \\ Institute of Zoology, the Chinese Academy of Sciences, Beijing 100080 \\ (Received May 5, 1994; Revised August 20, 1994)
}

\begin{abstract}
Wildlife trade is a main impetus for wildlife hunting. There are 91 species of animals, involved in the wildlife trade in Guangxi, China, including 40 species of mammals, 17 species of birds, 32 species of reptiles and 2 species of amphibians. Thirty-five species, including 21 species of mammals, 8 species of birds and 6 species of reptiles, are the anirnals under state's special protection. Thirty species are involved in the wildlife trade between China and Vietnam. There are 55 species involved in live wildlife trade. Thirty-nine species of wildlife are used as food or raw materials for medicinal liquor. Thirty-four species are used as medicinal materials. And 31 species (not including snakes) are used as raw materials. There are 9 species used as pets. The species richness involved in the wildlife trade in Guangxi tends to increase. Wildlife trade has caused the endangerment of many species and the decline of wildlife resources in Guangxi. The live wildlife trade between China and Vietnam can bring about an invasion of exotic species to China. It is suggested that the changes of species and volume involved in the wildlife trade should be monitored and the live wildlife trade between China and Vietnam should be prohibited in Guangxi.
\end{abstract}

Key words species richness, wildlife trade

\section{Introduction}

Wildlife trade is a main impetus to utilize wildlife. The change in species and volume involved in the wildlife trade may reflect conservation status, dynamics and exploited level of wildlife resources. The study on wildlife trade is the theoritical basis on which proposals as to limit trade on rare or endangered species can be made, and with which future monitoring of the trade can be compared. The result also can be used to evaluate conservation effects of protection measures and laws for biodiversity conservation. It is of great significance in guiding sustainable utilization of wildlife resources.

China is a country with an ancient civilization. The traditional catering trade, Chinese medical science, processing industry and animal-raising technique are well developed. Wildlife has been utilized for food, medicine, raw materials and pets for a long time in China. But the wildlife trade in China has never been monitored until recent years. The demand for wildlife and its products in China has quickly increased with economic development in recent years. This makes prices of wildlife and its products soaring. More and more companies

* This project was supported by a grant from the Biodiversity Working Group of CCICED 
or individuals raise wildlife and trade on wildlife and its products. Illegal activities, such as purchasing, reselling and smuggling, are very rampant. The wildlife trade has seriously threatened the survival of some species. Some animals under state's special protection are going to extinction because of illegal trade. Many animal resources are destroyed because of the vast trade. According to the analysis of the related data ( $\mathrm{Li}$ Yiming et al. 1993), 69.91\% of mammal species in China are threatened to different extents. The main factors that threaten mammal species are hunting and habitat change, and the hunting is a more important factor. Hunted bags are used as food, medicine and raw materials. The demand for wildlife and its products will further increase as economy quickly develops and population continuously expands in China. With habitat destruction and environment degradation resulted from recent advances in economic development, the number of species threatened will further increase, and the threatened degree of species will become more serious.

After China became a signatory state to the Convention on International Trade in Endangered Species of Wild Fauna and Flora in 1981, it is needed to provide a report about trade status of species that are banned for trade by the CITES every year. But little is known about the status of the wildlife trade in China. Many countries and areas in the world have launched investigation and study on wildlife trade. This plays a positive role in biodiversity conservation, economic development and sustainable exploitation of wildlife resources for these countries or areas or the world. There are few studies done on the wildlife trade in China. Even some rough estimations about this aspect are limited. Therefore, a comprehensive study on wildlife trade is urgently needed. Guangxi is one of the provinces with well-developed wildlife trade in China. Studying the status of the wildlife trade in this Province is very important.

\section{Site and method}

\subsection{Site}

The study was conducted in the Guangxi Zhuang Autonomous Region (Guangxi for short). Guangxi is located in south China (Fig.1). It is one of the richest species diversity

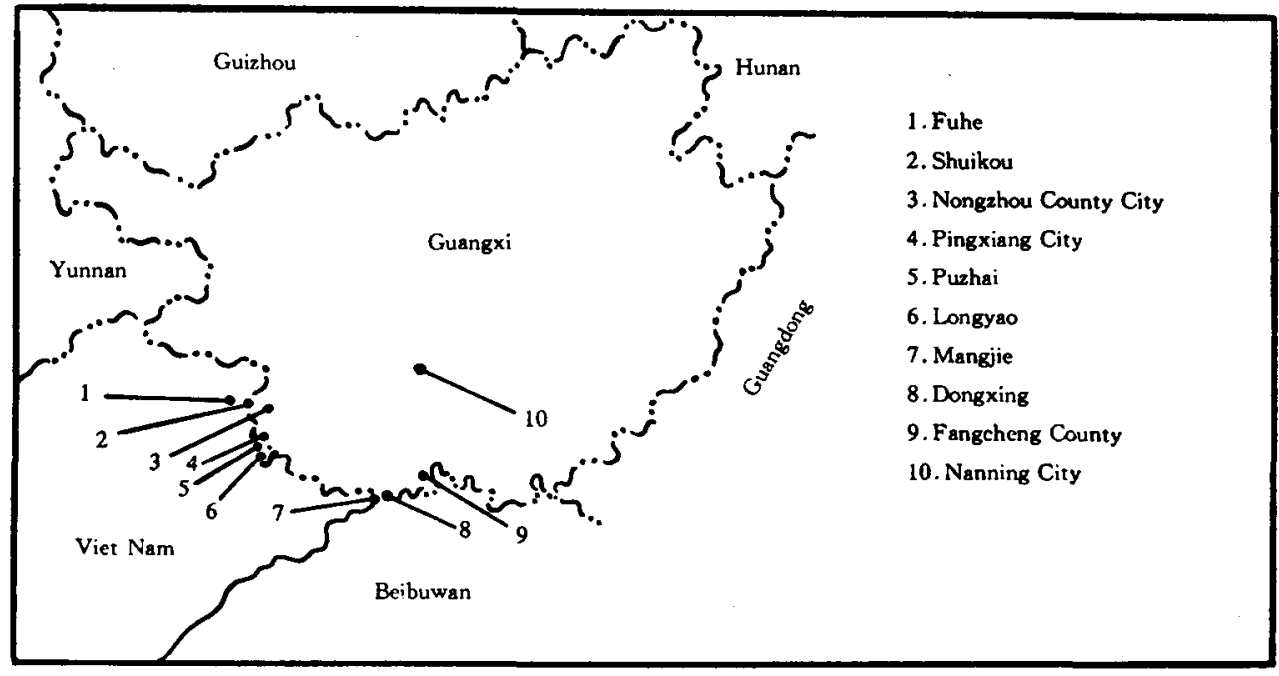

Fig. 1 The diagram of geographical position of Guangxi 
provinces in China, and this has always been the case that the local people in Guangxi eat wildlife. The traditional Chinese medicinal science in Guangxi is well developed. Guangxi may be a main corridor for the import and export of wildlife and its products from land and sea between China and the outside because of its geographical position.

\subsection{Methods}

The trade data of $1954 \sim 1993$ on live wildlife, pelts, medicinal materials and so on were collected from government-owned companies in Guangxi. Pharmacies, restaurants, agriculture trade markets, wildlife trade markets and pet shops in Nanning City, Pingxiang City, Longzhou County City and Dongxing Town in Fangcheng County were investigated (Fig. 1). Mammals, birds, reptiles and amphibians in the wildlife trade were checked. The Dongxing Customs, the Longyao Customs, the Puzhai Customs, the Shuikou Customs in China, an Mangjie Town, Fuhe Town in Vietnam were visited (Fig. 1), and species involved in wildlife border trade were checked.

\section{Results}

The study was conducted on December 4 30, 1993. In Nanning City, 11 agriculture trade markets, one wildlife trade market, 70 restaurants, 12 shops and 9 pharmacies were investigated. In Pingxiang City, one agriculture trade market, one wildlife trade market, 14 restaurants, one shop and one pharmacy were checked. In Longzhou County City, we surveyed one agriculture trade market, one wildlife trade market, 7 restaurants, 4 shops and 7 pharmacies. One agriculture trade market, one wildlife trade market and 9 restaurants were examined in Dongxing Town. Two pet shops were checked in Nanning City. The data of wildlife trade of 1954 1993 have been collected from Guangxi Import and Export Company of Grain and Oil, Guangxi Import and Export Company of Livestock Products and Guangxi Company of Medicinal Materials, which are responsible for the purchase and export of wildlife in Guangxi. The results (Table 1) show that there are 91 species of animals involved in the wildlife trade in Guangxi, which include 39 species of mammals, 17 species of birds, 32 species of reptiles and 2 species of amphibians. Thirty-five species including 21 species of mammals, 8 species of birds and 6 species of reptiles are the animals under special protection by the state. There are 30 species involved in the wildlife trade between China and Vietnam. There are 55 species involved in the live wildlife trade. Thirty-nine species of wildlife are used as food and drink. Thirty-four species of wildlife are used as medicinal materials. And 31 species ( not including snakes) of wildlife are used as raw materials, and 9 species used as pets. The species of Primates, Carnivore and Artiodactyla have the preponderance over those of other orders in mammal trade. The species of Falconiformes dominate over those of other orders in bird trade. The species of Testudoformes and Serpentiformes preponderate over those of other orders in reptile trade. Rhinopitecus avurculus, Zhengui (belonged to Testudoformes), Hegui (belonged to Testudoformes) do not distribute in China. They are imported from Vietnam. Myocastor coypus and Baxigui (belonged to Testudoformes) are introduced from abroad. Saiga tatarica and Elephas maximus do not live in Guangxi. It is noticed that the trade of the animals under state's special protection and their products has been prohibited by the Chinese government now. 
Table 1 The species richness involved in the wildlife trade in Guangxi

\begin{tabular}{|c|c|c|c|c|c|c|}
\hline \multirow[b]{2}{*}{ Species } & \multicolumn{6}{|c|}{ Trade } \\
\hline & $\begin{array}{c}\text { Live } \\
\text { wildlife }\end{array}$ & $\begin{array}{c}\text { Food and } \\
\text { drink }\end{array}$ & Medicines & $\begin{array}{c}\text { Raw } \\
\text { materials }\end{array}$ & Pets & Remarks \\
\hline Rhizomys sinensis & + & + & & & & \\
\hline Petaurista petaurista & + & & & & & \\
\hline Callosciurus erythraeus & + & & & + & + & 1 \\
\hline Myocastor coypus & + & & & & & \\
\hline Lepus sinensis & & + & & + & & 1 \\
\hline Erinaceus europaeus & & & + & & + & 1 \\
\hline Manis pentadactlyla * & + & + & + & & & 1,2 \\
\hline Nycticebus coucang * & + & & & + & & 1,2 \\
\hline Macaca arctoides" & + & & & + & + & 1 \\
\hline M. assamensis * & + & & & + & & 1,2 \\
\hline M. mulatta ${ }^{*}$ & + & & + & + & & 1,2 \\
\hline M. nemestrina* & + & & & + & + & 1,2 \\
\hline Presbytis francoisi ${ }^{*}$ & + & + & & + & & 1 \\
\hline Rhinopithecus avurcalus & + & & & & & 2 \\
\hline Callorhinus ursinus * & & + & + & & & 1 \\
\hline Elaphas maximus * & & & + & & & \\
\hline Nyctereutes procyonoides & & & & + & & 1 \\
\hline Mustela sibirica & + & & & + & & 1 \\
\hline Martes flavigula & & & & + & & 1 \\
\hline Mustela kathiah. & & & & + & & 1 \\
\hline Lutra lutra* & & & + & + & & 1 \\
\hline Melogale moschata & + & + & & + & & 1 \\
\hline Meles meles & & & & + & & 1 \\
\hline Arctonyx collaris & & & & + & & 1 \\
\hline Herpestes urva & & & & + & & 1 \\
\hline Paguma larvata & + & + & & + & & 1,2 \\
\hline Felis bengalensis & + & + & + & + & & 1,2 \\
\hline Viverra zibetha & + & & & + & & 1,2 \\
\hline Viverricula indica ${ }^{*}$ & + & + & & + & & 1,2 \\
\hline Selenarctos thibetanus * & & & + & + & & 1,2 \\
\hline Panthera pardus" & & & + & + & & 1,2 \\
\hline P. tigris ${ }^{*}$ & & + & + & + & & 1 \\
\hline Muntiacus reevesi & & & & + & & 1 \\
\hline Hydropotes inermis" & & & & + & & 1 \\
\hline Cervus nippon " & & + & + & + & $\therefore$ & 1 \\
\hline C. unicolor * & & & + & + & & 1 \\
\hline Elaphodus cephalophus & & & + & + & & 1 \\
\hline C. alaphus" & & + & + & + & & 1 \\
\hline Moschus berevouski & & & + & + & & 1 \\
\hline Saiga tatarica * & & & + & & & \\
\hline Rhasianus colchicus & + & + & & & & \\
\hline Centropus sinensis " & + & + & + & & & 1,2 \\
\hline Amaurorhis phoenicurus & + & & & & & 2 \\
\hline Emberiza aureola & & + & & & & \\
\hline Passer montanus & & + & & & & \\
\hline
\end{tabular}


Table 1 (Continued)

Garrula canorus

Charadrius leschenaultii

Psittacula alexandri *

Acridotheres cristatellus

Shuiluriao" (Ardeidae)

Anas platyrhynchos

Aegypius monachus *

Bubo bubo *

Houtouying * (Tytonidae)

Zhuying * (Accipiteridae)

Milvus korschun *

Shanying * (Accipitridae)

Naja naja

Ophiophagus hannah

Bungarus lasciutus

B. multicinctus

Ptyas mucosus

$P t$. korros

Agkistrodon acutus

Enhydris chinensis

Elaphe radiata

Python molurus" .

Caohuashe" " (Serpentiformes)

Opheodrys major

Sanxianshe * (Serpentiformes)

Elaphe carinata

Physignathus cocincinus

Elaphe moellendorffi

Zaocys dhumnades

Hydrophis Cyanocinctus

Platystenon megacephalum

Chinemys reevessi

Caretta caretta"

Hegui * * (Testudoformes)

Zhengui " (Testudoformes)

Changshougui * " (Testudoformes)

Hongbiangũ * * (Testudoformes)

Baxigui" * (Testudoformes)

Trionyx sinensis

Tr. steindachneri*

Eret mochelys imbricata *

Calotes versicolor

Varanus salvator *

Gekko gecko *

Rana nigromaculata

$R$. limnocharis

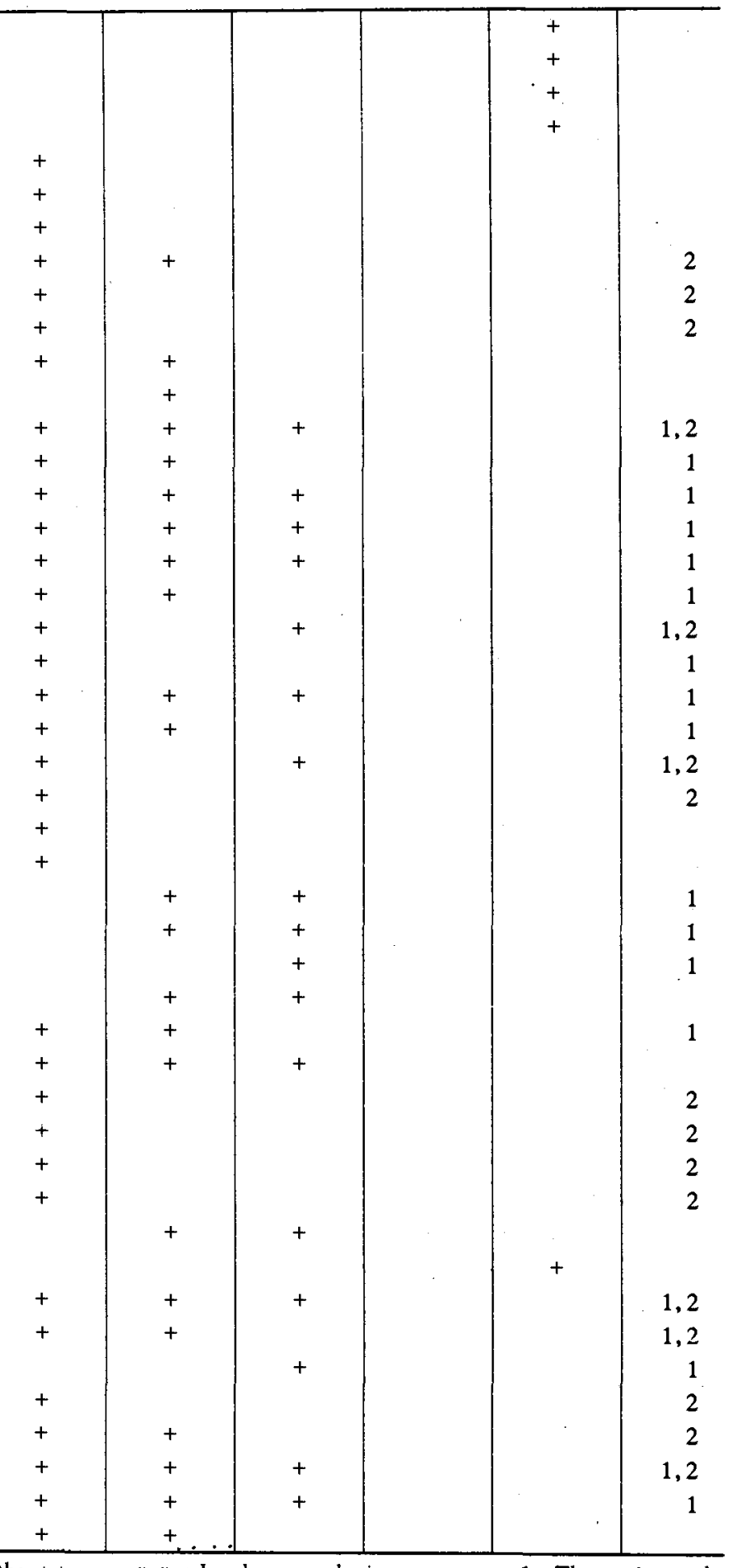

* = The animal under special protection by the state;

* * = Local name or business name;

$1=$ The species run by state-operated companies before 1983

$2=$ The species involved in the wildlife trade between Chine and Vietnam 
In recent years, the number of species involved in wildlife trade tends to increase. During 1954 1983, Chinese government implemented the policy of state monopoly for purchasing and marketing for wildlife. The free trade of wildlife had not been allowed. The stateoperated companies managed the wildlife trade. The number of species involved in the wildlife trade was small, but the trade volume of a few species were huge during this period. After the government opened the free wildlife trade in 1983, the number of species in markets began to increase, but the wildlife trade volume was hard to estimate. After the relationship between China and Vietnam became relaxant, a lot of wildlife from Vietnam was transported to Guangxi. This further raises the species richness involved in the wildlife trade in Guangxi.

\section{$4 \quad$ Discussion}

That the wildlife trade in Guangxi is much developed has four reasons. First, species diversity of wildlife is very rich in Guangxi, which provides enough resources for wildlife trade. Second, local people are used to eating wildlife and the traditional Chinese medicine is very flourishing in Guangxi, which supplies a lot of consumption markets for wildlife trade. Third, demand for wildlife and its products in neighbours of Guangxi, such as Guangdong Province, Hong Kong, Macao and so on, where wildlife and its products in Guangxi are exported to, are very large. Forth, wildlife and its products in Vietnam are transported into Guangxi, which increases the species richness in the wildlife trade in Guangxi, because the wildlife is very expensive and the demand for wildlife is huge in China.

Wildlife involved in the wildlife trade has two sources. First, it stems from direct hunting in the field. Second, it comes from raising and breeding wildlife, the ancestries of which still originate from direct hunting in the field. Therefore, in essence, wildiife involved in wildlife trade originally are the outcome of directly or indirectly hunting wild populations. According to the data of trade volume of some species from Guangxi state-operated companies, Panthera tigris, Presbytis francoisi, Nycticebus coucang, Python molurus and some other species in Guangxi have been endangered because of over-hunting. Other four species of Primates in Guangxi experienced such a great quantity of purchase during 1957 1960. The amount of purchase continued to decrease after 1975. Due to the over-hunting, the harvest yields of Paguma larvata, Melogale moschata, Viverra zibetha, Viverricula indica, Felis bengalensis and some snakes were obviously reduced in the $1980 \mathrm{~s}$. The catch of Gekko gecko has been declined in the 1980s due to the large quantity of purchase in the 1950s 1970s. Centropus sinensis was harvested so heavily in the 1960s $\sim 1970$ s that the catch of it in the $1980 \mathrm{~s}$ did not reach the original levels. Manis pentadatyla was greatly purchased in the 1970s, and the harvest yield of this animal in the 1980s $\sim 1990 \mathrm{~s}$ reduced enormously. The harvest yields of musk and bear gallbladder have been declined because of undue exploitation. Amounts of pet purchase of Lutra lutra and Nyctereutes procyonoides have tended to drop. In a word, over-exploitation of wildlife resources has made some species endangered and the resources declined in Guangxi. It needs to draft the trade control to prevent the wildlife resources from over-exploitation.

A lot of wildlife from Vietnam has been transported into China. This can have very harmful effects on the environment and wildlife conservation in China. The first harmful effect is that this live wildlife trade may produce exotic species problem. The direction of the live wildlife trade between China and Vietnam is that the live wildlife from Vietnam goes into 
China. This is likely to cause exotic species invasion (Coblentz 1990), which makes some endemic species extinct, biological resources destroyed, and biodiversity reduced in China. The exotics can bring some fatal epidemic diseases or parasites to the same species in China, which can also make some species extinct, the resources declined, and injure economic utilization of biological resources in our country. The second effect is that wildlife populations in China are threatened by live wildlife trade. The survival of some rare species that are distributed on the border between China and Vietnam, such as Nycticebus coucang, Macaca malatta, $M$. nemestrina, $M$. assamensis, Manis pentadactyla, Varanus salvator and so on, can be threatened because of the heavy hunting on the Victnam side.

The number and volume of species involved in the wildlife trade on the border between China and Vietnam are astonishing: This may be unprecedented in the history of international wildlife trade, and will cause long-term harmful effects on environment and wildlife conservation in both countries. It can cause environmental degradation, species extinction, and resource diminishment in both China and Vietnam. It is needed that Chinese government and Vietnam government pay greater attention to this problem, and take effective steps to prevent the live wildlife trade on the border between China and Vietnam as soon as possible.

Guangxi local government has taken many measures to control illegal trade of wildlife. Based on our study, the recommendations of wildlife conservation in Guangxi are that:

Strictly carry out The Wildlife Protection Law, and prohibit illegal trade of the animals under special protection by the state;

Make clear the wildlife resource capacity, and draft trade control measures;

Monitor the changes of species and volumes involved in the wildlife trade;

Prohibit live wildlife trade on the Sino-Vietnam border.

\section{REFERENCES}

Coblentz B E, 1990. Exotic organisms: a dilemma for conservation biology. Conservation Biology, 4 (3):261 $-265$

Li Yiming, Li Dianmo, 1993. The disturbed status and cause of species diversity in Mammalia in China: an analysis of 103 species and subspecies. In: Xia Wuping, Zhang Jie (eds.), The Succesional Changes of Mammals in China under the Influences of Human Activities, China Science \& Technology Press, 176 -184 (in Chinese) 